\title{
PENGARUH TINGKAT DEVIGORASI DAN KERAPATAN BENIH KRASIKARPA TERHADAP PERTUMBUHAN SEMAINYA
}

\author{
The Effect of Devigoration Level and Density of Krasikarpa Seeds on the Growth of Their Sprouts
}

\author{
Asep Rohandi dan/and Nurin Widyani \\ Balai Penelitian Teknologi Perbenihan Bogor \\ Jl. Pakuan Ciheuleut PO. BOX 105, Bogor - 16001 \\ Telp./Fax. (0251) 327768
}

Naskah masuk : 14 Februari 2007 ; Naskah diterima : 20 April 2007

\begin{abstract}
A major problem usually encountered during seed procurement of seeds is low vigor of long term stored seed, affecting in turn the success of outplanting. The objective of this study was to determine the effect of density krasikarpa (Acacia crassicarpa) seeds on the growth of their germinants in sowing bed. A completely randomized design with a single factor (i.e. seed densities) was used in this experiment. The density was arranged in 6 levels, which were predetermined based on the percentage of normal germinants of various seed lots. This variation was obtained through seed-ageing treatment at 6 durations, i.e. 0, 72, 120, 192, 216, and 240 hours (as devigoration levels). From each of those six levels seed density was measured, thereby acquiring in all 6 densities ranging from 50-66 seeds per $600 \mathrm{~cm}^{2}$ area. It turned out that ageing treatment (devigoration levels) for 240 hours caused decrease in percentage by about 23\% in comparison with the control (without ageing or at zero-hour ageing). Further, the different seed densities did not significantly affect vigor status of germinant, growth rate, growth uniformity/simultaneity, and delta value as well as the score-based nursery success. The decrease in seed vigor (devigoration) as much as 19-20\% could be overcome by increasing density as much as 16 seeds per $600 \mathrm{~cm}^{2}$ area. In general, the germinant of krasikarpa seeds still belonged to the normal criteria $(N)$, i.e. strongly normal $(K)$ and less strong $(K K)$, suggesting the potential survival rate of seedling in the field. This grouping implies the possibility of seed to survive in the field.
\end{abstract}

Key words: A. crassicarpa seeds, devigoration level, seed density, sprout, and growth

\begin{abstract}
ABSTRAK
Masalah utama yang dijumpai dalam pengadaan benih adalah rendahnya vigor, terutama sekali ketika disimpan untuk jangka waktu lama, dengan demikian mempengaruhi kesuksesan penanaman benih di lapangan. Berkaitan dengan hal tersebut, penelitian ini dilakukan dengan tujuan untuk mengetahui pengaruh tingkat devigorasi dan kerapatan benih $A$. crassicarpa terhadap pertumbuhan semainya di bedeng tabur. Penelitian ini menggunakan rancangan acak lengkap dengan faktor tunggal (kerapatan benih). Kerapatan bervariasi dalam 6 taraf, yang didasarkan pada sebelum ditentukannya persentase dari benih normal yang tumbuh di berbagai lot benih. Variasi ini didapat lewat perlakuan enam taraf pengusangan (penderaan), yaitu. 0, 72, 120, 192, 216, dan 240 jam (sebagai taraf devigorasi). Dari masing-masing enam taraf tersebut diukur kerapatan benih, dengan demikian diperoleh kisaran antara 50-66 benih setiap $600 \mathrm{~cm}^{2}$. Sampai tingkat penderaan 240 jam terlihat bahwa terjadi penurunan persentase pertumbuhan semai sekitar 23\% jika dibandingkan dengan kontrol (tanpa penderaan). Lebih lanjut, kerapatan benih yang berbeda tidak berpengaruh nyata terhadap status vigor perkecambahan, kecepatan dan keserempakan berkecambah, nilai delta serta keberhasilan persemaian. Penurunan vigor benih (devigorasi) sebanyak 19 - 20\% masih dapat diatasi dengan meningkatkan kerapatan benih sebanyak 16 benih setiap $600 \mathrm{~cm}^{2}$. Secara umum, kecambah krasikarpa masuk dalam kriteria normal (N), yaitu normal kuat (K) dan kurang kuat ( KK). Dengan pengelompokan seperti ini, dapat diketahui kemungkinan bibit tersebut dapat hidup berkelanjutan atau tidak sebelum dilakukan penanaman di lapangan.
\end{abstract}

Kata kunci : benih $A$. crassicarpa, tingkat devigorasi, kerapatan benih, semai, dan pertumbuhan 


\section{PENDAHULUAN}

\section{A. Latar Belakang}

Pelaksanaan program reboisasi dan rehabilitasi lahan serta pembangunan hutan tanaman masih menghadapi beberapa kendala dan tantangan, salah satunya adalah penyediaan benih/bibit berkualitas dalam jumlah yang cukup dan berkesinambungan. Untuk memenuhi hal tersebut diperlukan pengetahuan yang cukup mengenai teknik silvikultur terutama untuk jenis yang akan dikembangkan.

Untuk mengetahui mutu benih yang diproduksi dan yang akan digunakan, maka perlu dilakukan pengujian mutu benih. Ada berbagai macam pengujian mutu benih yang meliputi pengujian daya berkecambah atau daya tumbuh dan pengujian vigor. Pengujian daya berkecambah atau daya tumbuh memberikan informasi tentang kemungkinan tanaman berproduksi normal dalam kondisi lapang dan lingkungan yang serba normal atau optimum (Sadjad, 1980; Anonim, 2004). Sedangkan pengujian vigor merupakan pengujian perkecambahan yang biasa dilakukan di bawah kondisi yang kurang optimal atau di bawah cekaman seperti perlakuan penuaan dini (pengusangan) untuk mengetahui terjadinya kemunduran kualitas lot benih yang tidak nyata pada pengujian perkecambahan biasa (Anonim, 2004).

Permasalahan yang sering timbul dalam pengadaan benih kehutanan adalah vigor benih yang rendah, terutama jika disimpan dalam waktu yang cukup lama. Keadaan ini sangat mempengaruhi keberhasilan penanaman di lapangan. Untuk itu diperlukan penelitian mengenai kriteria vigor bibit/kecambah yang sampai saat ini masih jarang dilakukan untuk benih kehutanan.

Perkecambahan didefinisikan sebagai munculnya kecambah sampai pada struktur yang penting dapat berkembang lebih lanjut menjadi tanaman di bawah kondisi yang memadai dalam tanah (ISTA, 1996). Struktur benih tanaman tersebut berupa sistem perakaran, tunas pertumbuhan, kotiledon dan tunas pucuk. Perkecambahan benih juga merupakan salah satu indikator yang berkaitan dengan kualitas benih. Sehingga pengujian kecambah atau viabilitas harus menggambarkan kecambah yang potensial, yang jika dengan penanganan yang memadai harus merefleksikan hasil kecambah yang diharapkan pada saat berada di persemaian.

Pengamatan mengenai vigor bibit atau kecambah, penilaian terhadap komponen-komponen struktur vigor bibit atau kecambah seperti akar primer, akar sekunder, epikotil, hipokotil dan daun pertama sangatlah penting terutama jika kita ingin membedakan status vigor bibit yaitu bibit/kecambah yang tumbuh normal kuat, kurang kuat dan abnormal. Untuk membedakan status vigor bibit tersebut perlu kriteria tertentu sehingga dapat dilakukan pengelompokan secara tepat (Kartika, 1994). Dengan pengelompokan seperti itu dapat diketahui kemungkinan bibit tersebut dapat hidup berkelanjutan atau tidak sebelum dilakukan penanaman di lapangan.

\section{B. Tujuan}

Penelitian ini bertujuan untuk mengetahui pengaruh tingkat devigorasi dan kerapatan benih A. crassicarpa terhadap keberhasilan persemaiannya. 


\section{BAHAN DAN METODE}

\section{A. Lokasi dan Waktu}

Penelitian ini dilaksanakan di laboratorium dan rumah kaca Balai Penelitian dan Pengembangan Teknologi Perbenihan (BP2TP Bogor) dan dilakukan selama dua bulan dari bulan Desember 2003 sampai bulan Januari 2004.

\section{B. Bahan dan Alat}

Bahan dan alat yang digunakan adalah benih yang merupakan campuran (komposit) A. crassicarpa yang berasal dari Parungpanjang Bogor, Kalimantan Selatan dan Sumatera Selatan, kertas merang, alkohol, media perkecambahan (tanah dan pasir), alat untuk pengusangan, bak plastik, kain kasa, bak kecambah berukuran $600 \mathrm{~cm}^{2}$, sprayer, alat ukur, kantong plastik/polybag, bambu dan plastik naungan.

\section{Prosedur Penelitian}

\section{Persiapan Penelitian}

Persiapan yang dilakukan dalam penelitian ini adalah :

a. Seleksi benih

Seleksi benih dilakukan secara manual yaitu dengan memilih penampilan benih yang bagus, tidak keriput, keras dan sudah masak baik secara fisik maupun fisiologis.

b. Percobaan pendahuluan

Percobaan pendahuluan dilakukan untuk mengetahui cara pemecahan dormansi dan lamanya pengusangan benih A. crassicarpa.

c. Pengusangan (penderaan)

Pengusangan bertujuan untuk mendapatkan variasi vigor benih. Cara pengusangan yaitu benih dimasukkan di dalam wadah plastik yang telah diberi kawat kasa dan diisi air sebanyak $150 \mathrm{ml}$ kemudian ditutup dan air yang berada dalam wadah tidak mengenai benih. Wadah tersebut kemudian diletakkan dalam inkubator dengan suhu $40^{\circ} \mathrm{C}$. Faktor pengusangan terdiri dari 6 taraf, yaitu 0, 72, 120, 192, 216 dan 240 jam.

\section{Pelaksanaan Penelitian}

Penelitian ini terdiri dari dua eksperimen yaitu :

2.1. Pembedaan tingkat devigorasi (kemunduran benih)

Penelitian ini dilaksanakan dengan langkah-langkah sebagai berikut :

a. Setelah dipatahkan dormansinya (benih A. crassicarpa direndam dalam air mendidih dan dibiarkan selama 24 jam), kemudian benih diberi perlakuan devigorasi dengan pengusangan/penderaan (0, 72, 120, 192, 216 dan 240 jam). Pengusangan tersebut dilakukan untuk mendapatkan ragam lot benih.

b. Selanjutnya benih tersebut disemai pada campuran media tanah dan pasir dengan perbandingan 1:1 (v/v) di bak kecambah.

c. Penghitungan daya berkecambah benih $(\mathrm{N})$ untuk masing-masing taraf pengusangan. 


\subsection{Penentuan kerapatan benih}

Penentuan kerapatan benih dilakukan berdasarkan data hasil pengamatan pada eksperimen tahap pertama dengan langkah-langkah sebagai berikut :

a. Setelah diperoleh data daya berkecambah benih (N0, N1, N2, N3, N4, N5), maka akan didapatkan kerapatan benih yang akan digunakan. Penentuan kerapatan benih dihitung berdasarkan pada kelipatan nisbah bibit yang tumbuh normal setiap lot (N) terhadap kontrol. Jika kerapatan benih yang umum dilakukan yaitu 100 butir per $1200 \mathrm{~cm}^{2}$, maka kerapatan benih $(d)$ yang digunakan dalam penelitian ini adalah (Kartika, 1994) :

$$
\begin{array}{lr}
d 0=50 \text { butir } / 600 \mathrm{~cm}^{2}\left(600 \mathrm{~cm}^{2} \text { adalah ukuran bak kecambah }\right) \\
d 1=\frac{\mathrm{N} 0}{\mathrm{~N} 1} \times d 0 & d 4=\frac{\mathrm{N} 0}{\mathrm{~N} 4} \times d 0 \\
d 2=\frac{\mathrm{N} 0}{\mathrm{~N} 2} \times d 0 & d 5=\frac{\mathrm{N} 0}{\mathrm{~N} 5} \times d 0 \\
d 3=\frac{\mathrm{N} 0}{\mathrm{~N} 3} \times d 0 &
\end{array}
$$

b. Jumlah benih yang dibutuhkan didasarkan pada kerapatan benih yang sudah ditentukan (pada poin c di atas). Kemudian benih tersebut diusangkan sesuai dengan tingkat/taraf pengusangan yang digunakan.

c. Benih disemai pada bak-bak kecambah yang sudah tersedia. Bak-bak kecambah yang sudah ditanami disimpan di rumah kaca sesuai dengan rancangan yang digunakan.

Keberhasilan persemaian diuji berdasarkan tolak ukur nilai delta (D) sebagai berikut (Kartika, 1994) :

$$
\mathrm{D}=\frac{\mathrm{KK}}{\mathrm{T}} \times 100 \% \times \frac{\mathrm{A}+\mathrm{M}}{\mathrm{K}}
$$

dimana :

$\mathrm{KK}=$ jumlah bibit yang tumbuh normal kurang kuat

$\mathrm{T}=$ jumlah contoh bibit

$\mathrm{A}=$ jumlah bibit abnormal

$\mathrm{M}=$ jumlah bibit yang mati

$\mathrm{K}=$ jumlah bibit yang tumbuh normal kuat 
Untuk menghitung keberhasilan persemaian digunakan pendekatan fungsi (Kartika, 1994) :

$$
\mathrm{S}=\mathrm{f}(\mathrm{K}, \mathrm{D}-1, \mathrm{~T}-1)
$$

Keberhasilan persemaian ditentukan dengan rumus (Kartika, 1994) :

$$
S=\frac{K}{D \times T} \times 100 \% \times \frac{K K}{A+M}
$$

dimana :

$$
\begin{aligned}
& \mathrm{S}=\text { keberhasilan persemaian } \\
& \mathrm{KK}=\text { jumlah bibit yang tumbuh normal kurang kuat } \\
& \mathrm{T}=\text { jumlah contoh bibit } \\
& \mathrm{A}=\text { jumlah bibit abnormal } \\
& \mathrm{M}=\text { jumlah bibit yang mati } \\
& \mathrm{K}=\text { jumlah bibit yang tumbuh normal kuat } \\
& \mathrm{D}=\text { tolok ukur nilai delta }
\end{aligned}
$$

Pengamatan perkecambahan dilakukan setiap hari sampai tidak ada lagi kecambah yang tumbuh yaitu dengan mencatat jumlah kecambah normal yang tumbuh. Parameter yang diamati adalah daya berkecambah, kecepatan berkecambah dan keserempakan berkecambah. Perhitungan ini dihitung berdasarkan rumus sebagai berikut (ISTA, 1996) :

Daya Berkecambah $(\%)=\frac{\text { jumlah kecambah normal }}{\text { total benih yang ditabur }} \times 100 \%$

$$
\begin{aligned}
& \text { KcT }(\% / \text { hari })=\frac{\mathrm{N} 1}{\mathrm{D} 1}+\frac{\mathrm{N} 2}{\mathrm{D} 2}+\ldots \ldots \ldots .+\frac{\mathrm{Nn}}{\mathrm{Dn}} \\
& \text { KsT }(\%)=\frac{\text { jumlah kecambah normal kuat }}{\text { jumlah benih yang ditanam }} \times 100 \%
\end{aligned}
$$

dimana :

$$
\begin{array}{ll}
\mathrm{KcT} & =\text { kecepatan berkecambah } \\
\mathrm{N} 1 \ldots . . \mathrm{Nn} & =\text { kecambah normal } 1,2 \ldots . . . \mathrm{N} \text { dalam \% } \\
\mathrm{D} 1 \ldots . . \mathrm{Dn} & =\text { jumlah hari setelah tanam } \\
\mathrm{KsT} & =\text { keserempakan berkecambah }
\end{array}
$$




\section{Rancangan Penelitian}

Penelitian ini menggunakan Rancangan Acak Lengkap (RAL) satu faktor dengan tiga kali ulangan. Sebagai faktor adalah kerapatan benih (jumlah per satuan luas) di persemaian yang terdiri dari 6 taraf/tingkat (do, d1, d2, d3, d4, d5) yang ditentukan atas dasar persentase bibit normal dari lot benih yang beragam. Ragam lot benih didapatkan dengan perlakuan pengusangan/penderaan sebanyak 6 tingkat (0, 72, 120, 192, 216 dan 240 jam).

Pengolahan data menggunakan SAS Procedure GLM (Anonim, 1985). Untuk membedakan pengaruh kerapatan atau devigorasi terhadap peubah yang diamati maka dilakukan analisa sidik ragam dan uji DMRT pada taraf 5\%. Model liniernya adalah :

$$
\mathrm{Y}_{\mathrm{ij}}=\mu+\mathrm{A}_{\mathrm{i}}+\varepsilon_{\mathrm{ij}}
$$

dimana :

$$
\begin{array}{lll}
\mathrm{Y}_{\mathrm{ijk}} & = & \text { pengamatan pada tingkat kerapatan ke-i } \\
\mu & = & \text { rata-rata umum } \\
\mathrm{A}_{\mathrm{i}} & = & \text { pengaruh perlakuan kerapatan ke-i } \\
\varepsilon_{\mathrm{ijk}} & = & \text { galat percobaan }
\end{array}
$$

\section{HASIL DAN PEMBAHASAN}

\section{A. Perbedaan Tingkat Devigorasi (Kemunduran Benih)}

Hasil yang diperoleh dari perlakuan penderaan benih A. crassicarpa adalah terjadinya penurunan vigor awal benih dengan makin lamanya tingkat pengusangan. Hasil pengamatan daya berkecambah dan perhitungan kerapatan pada setiap tingkat pengusangan benih A. crassicarpa dalam penelitian ini dapat dilihat pada Tabel 1.

Tabel (Table) 1. Hasil pengamatan daya berkecambah dan perhitungan kerapatan pada setiap tingkat pengusangan benih A. crassicarp (The result of observation on germination level and the density of each seed - ageing level of A.crassicarp)

\begin{tabular}{|c|l|c|c|c|c|c|c|}
\hline \multirow{2}{*}{ No. } & \multicolumn{1}{|c|}{$\begin{array}{c}\text { Parameter } \\
\text { (Parameter) }\end{array}$} & \multicolumn{5}{c|}{$\begin{array}{c}\text { Lama Pengusangan (jam) } \\
\text { (Seed - ageing length) (hour) }\end{array}$} \\
\cline { 3 - 9 } & \multicolumn{1}{|c}{$\begin{array}{c}0 \\
(\mathrm{~N} 0)\end{array}$} & $\begin{array}{c}72 \\
(\mathrm{~N} 1)\end{array}$ & $\begin{array}{c}120 \\
(\mathrm{~N} 2)\end{array}$ & $\begin{array}{c}192 \\
\text { (N3) }\end{array}$ & $\begin{array}{c}216 \\
\text { (N4) }\end{array}$ & $\begin{array}{c}240 \\
\text { (N5) }\end{array}$ \\
\hline 1. & $\begin{array}{l}\text { Daya Berkecambah / } \\
\text { (Germination level) (\%) }\end{array}$ & 81 & 79 & 75 & 71 & 65 & 62 \\
\hline 2. & $\begin{array}{l}\text { Kerapatan (butir/bak kecambah)/ } \\
\text { [Density (number of seed/germination)] }\end{array}$ & 50 & 52 & 54 & 58 & 63 & 66 \\
\hline
\end{tabular}

Perbedaan karakter benih memberikan persentase vigor awal kecambah yang berbeda. Pada tingkat penderaan 240 jam terlihat bahwa A. crassicarpa mengalami penurunan sebesar $19 \%$ dari kontrol (tanpa penderaan). Hal ini diduga karena struktur kulit benih A. crassicarpa cukup keras yang menyebabkan kerusakan benih menjadi lebih lambat. Kondisi seperti ini terjadi juga pada benih Acacia mangium dimana pada pengusangan 480 jam tidak memberikan pengaruh yang nyata terhadap daya kecambah. Hal ini menunjukan bahwa lama pengusangan yang diujikan belum efektif untuk jenis 
ini. Sedangkan untuk jenis Paraserianthes falcataria semakin lama penderaan dilakukan pada benih maka daya berkecambah mempunyai kecenderungan makin menurun (Zanzibar, 2003).

Persentase vigor benih pada benih A. crassicarpa menunjukkan bahwa makin lama pengusangan makin menurun persentasenya, walaupun penurunan yang terjadi tidak drastis (Gambar 1). Penurunan ini menandakan terjadinya kemunduran benih. Kemunduran benih yang terjadi menandakan turunnya kualitas atau viabilitas benih yang mengakibatkan rendahnya vigor dan jeleknya pertumbuhan tanaman serta produksinya (Sutopo, 1995).

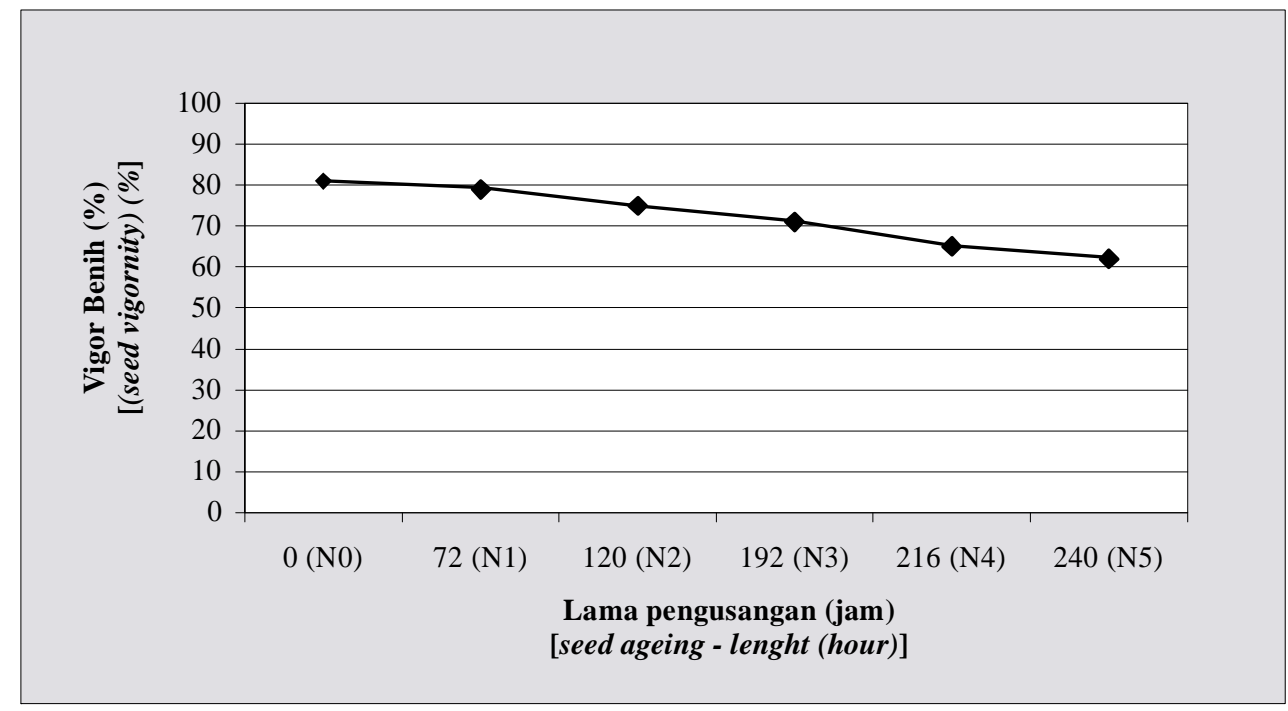

Gambar (Figure) 1. Persentase vigor benih A. Crassicarpa (Precentage of the vigority of A. crassicarpa seed)

Menurunnya daya kecambah benih (Gambar 1) merupakan salah satu perubahan fisiologi dari kemunduran benih. Kemunduran benih pada benih yang diuji terjadi akibat perlakuan yang diberikan pada benih yaitu lamanya penderaan, dimana makin lama pengusangan maka daya kecambah benih menurun.

Berdasarkan persentase vigor kecambah (Tabel 1), maka didapatkan kerapatan masing-masing benih setiap bak kecambah. Hasil perhitungan menunjukkan bahwa semakin rendah persentase vigor kecambah maka kerapatan benih A. crassicarpa lebih rapat per bak kecambah. Diharapkan penurunan vigor benih dapat diatasi dengan peningkatan kerapatan benih yang akan meningkatkan jumlah kecambah normal kuat yang akan digunakan untuk kegiatan penanaman selanjutnya.

\section{B. Pengaruh Kerapatan Terhadap Vigor Kecambah}

Vigor benih dapat diartikan sebagai kapasitas benih yang dapat menentukan potensi kemunculan dan perkembangan semai secara normal, cepat dan seragam pada kondisi lapangan yang beragam (Anonim, 2004). Berdasarkan hasil penelitian awal, maka dilakukan penanaman dengan kerapatan (jumlah persatuan luas) yang berbeda yang menghasilkan status vigor kecambah pada benih yang diuji. Pengamatan vigor kecambah untuk jenis $A$. crassicarpa tersebut dilakukan pada umur 7 minggu. 
Data hasil pengamatan menunjukkan bahwa kerapatan benih tidak berbeda nyata terhadap semua parameter yang diamati. Hasil tersebut berarti bahwa penambahan jumlah benih terhadap kontrol dengan meningkatkan kerapatan benih saat penaburan untuk mengatasi penurunan vigor (devigorasi) pada semua taraf pengujian masih bisa dilakukan. Penurunan vigor benih tertinggi dari d0 (81\%) menjadi d5 (62\%) sebesar 19\% masih dapat diatasi dengan peningkatan kerapatan benih 16 butir/bak kecambah. Hasil yang dilaporkan oleh Saptono (1988) memperlihatkan bahwa penambahan jumlah benih kedelai yang ditanam dapat digunakan untuk mengatasi penurunan produksi akibat menurunnya status vigor benih sampai 63\% sepanjang kondisi lingkungan optimum. Komposisi vigor kecambah masing-masing perlakuan selengkapnya tercantum pada Tabel 2.

Tabel (Table) 2. Rata-rata jumlah populasi bibit normal kuat (K), normal kurang kuat (KK), abnormal (A) dan mati (M) [(The average of population of normal strong (K), less strong (KK), abnormall (A) \& mortal seed $(M)]$

\begin{tabular}{|c|c|c|c|c|c|}
\hline \multirow{2}{*}{ No. } & \multirow{2}{*}{$\begin{array}{c}\text { Kerapatan Benih } \\
\text { (seed density) }\end{array}$} & \multicolumn{4}{|c|}{$\begin{array}{c}\text { Status Vigor Kecambah (\%) } \\
\text { (status of seeds vigor) }\end{array}$} \\
\cline { 3 - 6 } & & $\mathrm{K}$ & $\mathrm{KK}$ & $\mathrm{A}$ & $\mathrm{M}$ \\
\hline 1. & $\mathrm{~d} 0$ & 45.557 & 50.070 & 4.373 & 0.000 \\
\hline 2. & $\mathrm{~d} 1$ & 54.763 & 39.757 & 5.483 & 0.000 \\
\hline 3. & $\mathrm{~d} 2$ & 52.890 & 38.863 & 8.243 & 1.587 \\
\hline 4. & $\mathrm{~d} 3$ & 51.710 & 42.380 & 5.907 & 2.653 \\
\hline 5. & $\mathrm{~d} 4$ & 52.200 & 43.353 & 4.447 & 0.000 \\
\hline 6. & $\mathrm{~d} 5$ & 36.190 & 57.583 & 6.227 & 0.710 \\
\hline
\end{tabular}

Data pada Tabel 2 menunjukkan bahwa dari populasi kecambah yang diamati, secara umum status vigor kecambah masuk dalam kriteria normal (N) yaitu Normal Kuat (K) dan Normal Kurang Kuat (KK). Hal ini menunjukkan perlakuan kerapatan cenderung tidak berbeda nyata terhadap persentase status vigor kecambah. Presentase kecambah normal kuat (K) A. crassicarpa cenderung lebih besar dibanding kecambah normal kurang kuat (KK) yaitu untuk kerapatan d1, d2, d3, d4. Penampilan kecambah sebagian besar mempunyai diameter leher akar cukup besar, apabila kondisi ini terus bertahan sampai umur sapih, maka diprediksikan pada penanaman di lapangan tingkat keberhasilannya akan lebih tinggi karena bagian tersebut cenderung mempunyai cadangan makanan yang lebih banyak (Duryea, 1984).

Hasil analisa sidik ragam (Lampiran 1) menunjukan bahwa perbedaan perlakuan kerapatan benih tidak berpengaruh nyata terhadap status vigor kecambah, nilai delta dan keberhasilan persemaian untuk $A$. crassicarpa. Kemungkinan hal ini disebabkan pada semua tingkat kerapatan kecambah masih dapat mengambil nutrisi untuk mencukupi kebutuhan hidupnya. Pada jenis $A$. crassicarpa perlakuan kerapatan benih berpengaruh nyata terhadap status vigor kecambah Normal Kuat (K) dan Normal Kurang Kuat (KK). Proses pengambilan nutrisi pada tingkat kerapatan lebih rendah cenderung menghasilkan persentase kecambah normal kuat yang lebih besar dibanding pada tingkat kerapatan yang tinggi. Pada tingkat kerapatan rendah pengambilan nutrisi akan lebih optimal karena persaingan yang relatif sedikit. Hasil penelitian Hamid (2004) menunjukkan bahwa penggunaan benih padi dengan kerapatan lebih rendah yaitu 30, 40, $50 \mathrm{~kg} / \mathrm{ha}$ menghasilkan produksi yang lebih tinggi dibandingkan dengan jumlah benih 60, 70, $80 \mathrm{~kg} / \mathrm{ha}$ yang disebabkan oleh letak benih yang ditebar lebih renggang sehingga tanaman lebih leluasa memperoleh hara, udara dan cahaya 
matahari. Padi dengan kerapatan rendah menghasilkan pertumbuhan anakan cukup banyak dengan malai yang cukup panjang dan besar, sedangkan penanaman dengan kerapatan tinggi menyebabkan tanaman menjadi kerdil, anakan kurang dan banyak mati sebelum terbentuk malai.

Meskipun semua kerapatan benih tidak berpengaruh terhadap vigor kecambah, tetapi pada tingkat kerapatan yang tinggi dijumpai sebagian tanaman yang mengalami kematian karena dumping off. Kondisi demikian disebabkan oleh tingkat kelembaban yang cukup tinggi. Air yang berlebihan hampir selalu merusak karena air akan cenderung menggantikan udara sehingga akan terjadi pemadatan yang akan membatasi respirasi. Kelebihan air akan mendorong perkembangan penyakit yang disebabkan oleh jamur dumping off (Schmidt, 2000). Dumping off juga dapat terjadi apabila ada patogen yang terbawa oleh benih dan menjadi aktif segera setelah benih disebar atau disemaikan sehingga benih menjadi busuk sebelum atau sesudah benih berkecambah (Sutopo, 2002). Hal ini perlu menjadi pertimbangan dalam aplikasi di lapangan.

Nilai keberhasilan persemaian (S) dan nilai delta (D) didapatkan setelah kecambah siap sapih. Pada tahap ini perbedaan bentuk fisik atau penampilan kecambah dapat terlihat dari karakteristik morfologisnya yang merupakan salah satu kriteria kualitas bibit. Nilai delta dan keberhasilan persemaian untuk masing-masing perlakuan disajikan pada Tabel 3.

Tabel (Table) 3. Rata-rata kecepatan tumbuh (KcT), keserempakan tumbuh (KsT), Nilai delta (D) dan keberhasilan persemaian (S) [(The average of growth rate (KcT), growth uniformity / simultanity (KsT), delta value (D), and the score-based hursery success (S)]

\begin{tabular}{|c|c|c|c|c|c|}
\hline No. & \multirow{2}{*}{$\begin{array}{c}\text { Kerapatan Benih } \\
\text { (Seed Density) }\end{array}$} & \multicolumn{4}{|c|}{ Parameter (Parameter) } \\
\cline { 3 - 6 } & & $\begin{array}{c}\text { KcT } \\
(\% / h a r i)\end{array}$ & $\begin{array}{c}\text { KsT } \\
(\%)\end{array}$ & $\begin{array}{c}\text { D } \\
(\%)\end{array}$ & $\begin{array}{c}\text { S } \\
(\%)\end{array}$ \\
\hline 1. & d0 & 8.1893 & 0.33333 & 0.0480 & 1.827 \\
2. & d1 & 8.7173 & 0.44667 & 0.0387 & 2.047 \\
3. & d2 & 9.3937 & 0.39667 & 0.0837 & 0.353 \\
4. & d3 & 9.9290 & 0.34333 & 0.0893 & 0.253 \\
5. & d4 & 9.0600 & 0.33333 & 0.0370 & 2.093 \\
6. & d5 & 9.4553 & 0.26667 & 0.1270 & 0.490 \\
\hline
\end{tabular}

Dari Tabel 3 terlihat bahwa kecepatan tumbuh, keserempakan tumbuh, nilai delta dan nilai keberhasilan persemaian cenderung tidak berbeda nyata pada Uji Duncan, kecuali perlakuan kerapatan d5, dimana pada perlakuan ini didapatkan nilai delta terbesar. Hasil penelitian yang dilaporkan oleh Kartika (1994) pada benih Paraserianthes falcataria dan Acacia mangium menunjukkan bahwa makin lama tingkat devigorasi maka nilai delta akan makin besar. Hal ini diduga karena struktur kulit benih jenis-jenis tersebut yang cukup keras sehingga menyebabkan proses kerusakan benih menjadi lebih lambat. Apabila dilihat dari kecepatan tumbuh, perlakuan pada kerapatan rendah (d0) memiliki nilai terkecil dibanding perlakuan-perlakuan lainnya walaupun secara keseluruhan dalam uji duncan tidak berbeda nyata. Bilman (2001) menjelaskan bahwa semakin tinggi tingkat kerapatan maka akan memacu penyerapan unsur hara, air dan cahaya antar tanaman dalam luasan tertentu. Tanaman akan menunjukkan laju pertumbuhan memanjang dalam usaha mengoptimalkan penyerapan cahaya matahari untuk keperluan fotosintesis. Parameter ini sangat penting untuk diketahui karena kecepatan tumbuh merupakan ukuran kunci dalam keberhasilan di lapangan (Anonim, 1983). 


\section{KESIMPULAN}

Devigorasi benih A. crassicarpa sampai tingkat penderaan 240 jam dapat menurunkan vigor benih sampai $19 \%$ terhadap kontrol (tanpa penderaan). Perbedaan kerapatan benih tidak berpengaruh nyata terhadap status vigor kecambah, nilai delta dan keberhasilan persemaian A. crassicarpa. Penambahan jumlah benih dengan peningkatan kerapatan untuk mengatasi penurunan vigor (devigorasi) benih masih dapat dilakukan pada semua taraf pengujian. Penurunan vigor benih tertinggi yaitu sebesar 19\% terhadap kontrol masih dapat diatasi dengan peningkatan kerapatan benih 16 butir/bak kecambah untuk menghasilkan kecambah normal. Secara umum kecambah A. crassicarpa sampai umur 7 minggu masuk dalam kriteria normal (N) yaitu normal kuat (K) dan kurang kuat (KK).

\section{DAFTAR PUSTAKA}

Anonim. 1983. Seed Vigor Testing Handbook. Contribution No. 32 To The Handbook On Seed Testing. Association Official Seed Analysis.

Anonim. 1985. SAS user's guide: Statistics, version 5 edition. SAS Institute Inc., Cary, NC.

Anonim. 2004. Kamus Biologi dan Teknologi Benih. Direktorat Perbenihan Tanaman Hutan. Direktorat Jenderal Rehabilitasi Lahan dan Perhutanan Sosial. Departemen Kehutanan. Jakarta.

Bilman, W. S. Analisisis Pertumbuhan Tanaman Jagung Manis (Zea mays saccharata), Pergeseran Komposisi Gulma Pada Beberapa Jarak Tanam. Jurnal Ilmu-Ilmu Pertanian Indonesia Vol. 3 No 1, 2001. Hal 25-30. www.geocities.com/ejurnal/files/jipi /2001/25.pdf. Tanggal 21 Desember 2006.

Duryea, M. L. 1984. Nursery Cultural Practices : Impacts on Seedling Quality. Forest Nursery Manual : Laboratorium, Oregon State University, Corvallis. 143-145 pp.

ISTA. 1996. International Rules for Seed Testing, Rules 1996. International Seed Testing Association (ISTA). Seed Science and Technology 24 (supplement). Zurich, Switzerland.

Hamid, A. 2004. Penentuan Jumlah Benih Padi Sebar Langsung untuk Menekan Pertumbuhan Gulma. Buletin Teknik Pertanian Vol. 9 No. 1, 2004. Hal 1-3. www.pustakadeptan.go.id/publication/bt091041.pdf. Tanggal 21 Desember 2006.

Kartika, E. 1994. Penentuan Kriteria Vigor Bibit serta Pengaruh Tingkat Devigorasi dan Kerapatan Benih terhadap Keberhasilan Persemaian Paraserianthes falcataria (L.) dan Acacia mangium Wild. Disertasi Program Pascasarjana IPB. Bogor. Tidak diterbitkan.

Sadjad, S. 1980. Panduan Pembinaan Mutu Benih Tanaman Hutan di Indonesia. Direktorat Reboisasi dan Rehabilitasi, Direktorat Jenderal Kehutanan - Lembaga Afiliasi IPB. Bogor.

Saptono, G. 1988. Hubungan Antara Vigor Benih Pratanam dan Jumlah Benih yang Ditanam dengan Produksi pada Kedelai (Glycine max L. Merr.) Varietas Orba. Karil. Fakultas Pertanian, Institut Pertanian Bogor. Bogor. 46 hal.

Schmidt, L. 2000. Pedoman Penanganan Benih Tanaman Hutan Tropis dan Sub Tropis (Terjemahan). Kerjasama Direktorat Jenderal RLPS dan IFSP. PT. Gramedia. Jakarta. 530 hal.

Sutopo, L. 2002. Teknologi Benih. PT Raja Grafindo Persada. Jakarta. 
Zanzibar, M. 2003. Kemunduran Viabilitas Beberapa Benih Pohon Hutan Akibat Pengaruh Perlakuan Pengusangan. Buletin Teknologi Perbenihan Vol. 10 No.1. Badan Penelitian dan Pengembangan Kehutanan. Pusat Penelitian dan Pengembangan Bioteknologi dan Pemuliaan Tanaman Hutan. Bogor. 
Lampiran (Annex) 1. Anova pengaruh devigorasi dan kerapatan benih terhadap vigor kecambah dan keberhasilan persemaian A. Crassicarpa (ANOVA of effect of devigoration and seed density on the vigority of germinant and the successfulhest of A. crassicarpa)

\begin{tabular}{|c|c|c|c|c|c|}
\hline $\begin{array}{l}\text { Parameter } \\
\text { (Parameter) }\end{array}$ & $\begin{array}{c}\text { Sumber Keragaman } \\
\text { (Vanation) }\end{array}$ & DB & $\begin{array}{l}\text { Jumlah Kuadrat } \\
\text { (Number of } \\
\text { square) }\end{array}$ & $\begin{array}{l}\text { Kuadrat Tengah } \\
\text { (Median square) }\end{array}$ & $\begin{array}{c}\text { F-hitung } \\
\text { (an nursery) }\end{array}$ \\
\hline $\begin{array}{l}\text { Normal Kuat } \\
\text { (Normal Strong) }\end{array}$ & $\begin{array}{l}\text { Perlakuan (Treatment) } \\
\text { Galat (Error) } \\
\text { Total Terkoreksi } \\
\text { (Total Corrected) }\end{array}$ & $\begin{array}{c}5 \\
12 \\
17\end{array}$ & $\begin{array}{r}725.41651667 \\
373.89913333 \\
1099.31565000\end{array}$ & $\begin{array}{r}145.08330333 \\
31.15826111\end{array}$ & $4.66^{\mathrm{ns}}$ \\
\hline $\begin{array}{l}\text { Kurang Kuat } \\
\text { (Less Strong) }\end{array}$ & $\begin{array}{l}\text { Perlakuan (Treatment) } \\
\text { Galat (Error) } \\
\text { Total Terkoreksi }\end{array}$ & $\begin{array}{c}5 \\
12 \\
17\end{array}$ & $\begin{array}{r}774.30357778 \\
459.16006667 \\
1233.46364444\end{array}$ & $\begin{array}{r}154.86071556 \\
38.26333889\end{array}$ & $4.05^{\mathrm{ns}}$ \\
\hline $\begin{array}{l}\text { Abnormal } \\
\text { (Abnormal) }\end{array}$ & $\begin{array}{l}\text { Perlakuan (Treatment) } \\
\text { Galat (Error) } \\
\text { Total Terkoreksi } \\
\text { (Total Corrected) }\end{array}$ & $\begin{array}{c}5 \\
12 \\
17\end{array}$ & $\begin{array}{r}30.38420000 \\
74.53980000 \\
104.92400000\end{array}$ & $\begin{array}{l}6.07684000 \\
6.21165000\end{array}$ & $0.98^{\mathrm{ns}}$ \\
\hline $\begin{array}{l}\text { Mati } \\
\text { (Dead) }\end{array}$ & $\begin{array}{l}\text { Perlakuan (Treatment) } \\
\text { Galat (Error) } \\
\text { Total Terkoreksi } \\
\text { (Total Corrected) }\end{array}$ & $\begin{array}{c}5 \\
12 \\
17\end{array}$ & $\begin{array}{l}17.93411667 \\
31.96673333 \\
49.90085000\end{array}$ & $\begin{array}{l}3.58682333 \\
2.66389444\end{array}$ & $1.35^{\mathrm{ns}}$ \\
\hline $\begin{array}{l}\text { Kecepatan } \\
\text { Tumbuh } \\
\text { (Growing Speed) }\end{array}$ & $\begin{array}{l}\text { Perlakuan (Treatment) } \\
\text { Galat (Error) } \\
\text { Total Terkoreksi } \\
\text { (Total Corrected) }\end{array}$ & $\begin{array}{c}5 \\
12 \\
17\end{array}$ & $\begin{array}{l}5.62080711 \\
3.81254467 \\
9.43335178\end{array}$ & $\begin{array}{l}1.12416142 \\
0.31771206\end{array}$ & $3.54^{\mathrm{ns}}$ \\
\hline $\begin{array}{l}\text { Keserempakan } \\
\text { Tumbuh } \\
\text { (Growth } \\
\text { Simultanity) }\end{array}$ & $\begin{array}{l}\text { Perlakuan (Treatment) } \\
\text { Galat (Error) } \\
\text { Total Terkoreksi } \\
\text { (Total Corrected) }\end{array}$ & $\begin{array}{c}5 \\
12 \\
17\end{array}$ & $\begin{array}{l}0.05700000 \\
0.02620000 \\
0.08320000\end{array}$ & $\begin{array}{l}0.01140000 \\
0.00218333\end{array}$ & $5.22^{\mathrm{ns}}$ \\
\hline $\begin{array}{l}\text { Delta } \\
(\text { Delta })\end{array}$ & $\begin{array}{l}\text { Perlakuan (Treatment) } \\
\text { Galat (Error) } \\
\text { Total Terkoreksi } \\
\text { (Total Corrected) }\end{array}$ & $\begin{array}{c}5 \\
12 \\
17\end{array}$ & $\begin{array}{l}0.01908628 \\
0.01811200 \\
0.03719828\end{array}$ & $\begin{array}{l}0.00381726 \\
0.00150933\end{array}$ & $2.53^{\mathrm{ns}}$ \\
\hline $\begin{array}{l}\text { Keberhasilan } \\
\text { Persemaian } \\
\text { (Success nursery) }\end{array}$ & $\begin{array}{l}\text { Perlakuan (Treatment) } \\
\text { Galat (Error) } \\
\text { Total Terkoreksi } \\
\text { (Total Corrected) }\end{array}$ & $\begin{array}{c}5 \\
12 \\
17\end{array}$ & $\begin{array}{l}12.06630828 \\
21.97352867 \\
34.03983694\end{array}$ & $\begin{array}{l}2.41326166 \\
1.83112739\end{array}$ & $1.32^{\mathrm{ns}}$ \\
\hline
\end{tabular}

Keterangan (note) $: \mathrm{ns}=$ tidak berpengaruh nyata pada selang kepercayaan $95 \%$

[(Remarks) : ns = insignificant on 95\% level) confiden] 